\title{
Financial Inclusion and Demand for Money: A Dynamic Panel Data Approach
}

\author{
Zelin Nurfadia Sidik ${ }^{1}$, Noer Azam Achsani ${ }^{2}$, Syamsul Hidayat Pasaribu ${ }^{3}$
}

\begin{abstract}
Financial inclusion is designed to increase the opportunities and society participation in the formal financial institution, especially for unbanked people. Moreover, financial inclusion is one of strategy inclusive economic growth. However, financial inclusion may lead an ineffectiveness of monetary policy. It is because financial inclusion can affect the sensitivity of interest rate, and it could cause instability demand for money. Therefore, the research aims to analyze the impact of financial inclusion on demand for money, reserve money (MO), in 36 countries for the period 2004 to 2014. The method that used is Dynamic Panel Approach. The result shows that financial inclusion stimulates the increase of demand for reserve money (MO) in developed countries. In the other hand, the increasing of financial inclusion could decrease the demand for reserve money (MO) in developing countries.
\end{abstract}

Keywords: financial inclusion, demand for money, dynamic panel data

\begin{abstract}
Abstrak
Inklusi keuangan dirancang untuk meningkatkan kesempatan dan partisipasi masyarakat miskin dalam lembaga keuangan formal, khususnya bagi masyarakat unbanked. Selain itu, inklusi keuangan merupakan salah satu strategi untuk meningkatkan pertumbuhan ekonomi yang inklusif. Tetapi, inklusi keuangan dapat menyebabkan ketidakefektifan pelaksanaan kebijakan moneter. Hal ini dikarenakan inklusi keuangan memengaruhi sensitivitas suku bunga sehingga menyebabkan ketidakstabilan pada permintaan uang. Oleh karena itu, tujuan dari penelitian adalah menganalisis dampak inklusi keuangan terhadap permintaan uang, uang primer (MO), di 36 negara selama periode 2004-2014. Metode yang digunakan adalah Data Panel Dinamis. Hasilnya menunjukkan bahwa inklusi keuangan menyebabkan peningkatan permintaan uang primer (MO) di negara maju. Sebaliknya, peningkatan inklusi keuangan menyebabkan penurunan permintaan uang primer (MO) di negara berkembang.
\end{abstract}

Kata Kunci: keuangan inklusif, permintaan uang, panel dinamis

\section{How to Cite:}

Sidik, Z. N., Achsani, N. A., \& Pasaribu, S. H. (2018). Financial Inclusion and Demand for Money: a Dynamic Panel Data Approach. Signifikan: Jurnal Ilmu Ekonomi. Vol. 7 (2): 137 - 148. doi: http//dx.doi.org/10.15408/ sjie.v7i2.6838. 


\section{Introduction}

The inclusive of economic growth is the main focus of economic policy across the country to reduce the country's poverty rate. As the way to achieve that, the development of the financial sector and financial inclusion must be prioritized in sustainable development agenda and monetary policy. Implementation of an inclusive financial system can encourage economic activity among the people who are economically excluded from financial services, so it can encourage equity in the distribution of income and poverty alleviation (Bank of Indonesia 2014).

The term of financial inclusion became a trend after the global financial crisis in 2008, it because the crisis has a high impact for low-income society and also generally unbanked people in developing country. The poor society would be more impoverished continuously if the barriers for accessing financial services are not dispensed and the existing of financial exclusion still obstructing unbanked people to access financial institution (Demirgüc-Kunt et al. 2008). The financial inclusion is implemented to facilitate people especially unbanked people in utilizing the function of the formal financial institution with affordable cost and no barriers to access that.

Financial inclusion has a positive correlation with the income level of a country. A study conducted by Sarma (2012) found a positive relationship between financial inclusion and income level, which means that most of the high Index of Financial Inclusion (IFI) countries have high-level income. Figure 1 shows that average of IFI in the developed country is higher than in developing country. The average index of financial inclusion (IFI) in developed countries rose from 0.41 in 2010 to 0.43 in 2014. In the other hand, the average of IFI in developing countries is 0.18 in 2010 and increased to 0.20 in 2014. It concludes that the index of financial inclusion (IFI) in developing countries is lower than developed countries.

Figure 1. Index of Financial Inclusion (IFI) in Developed and Developing Country

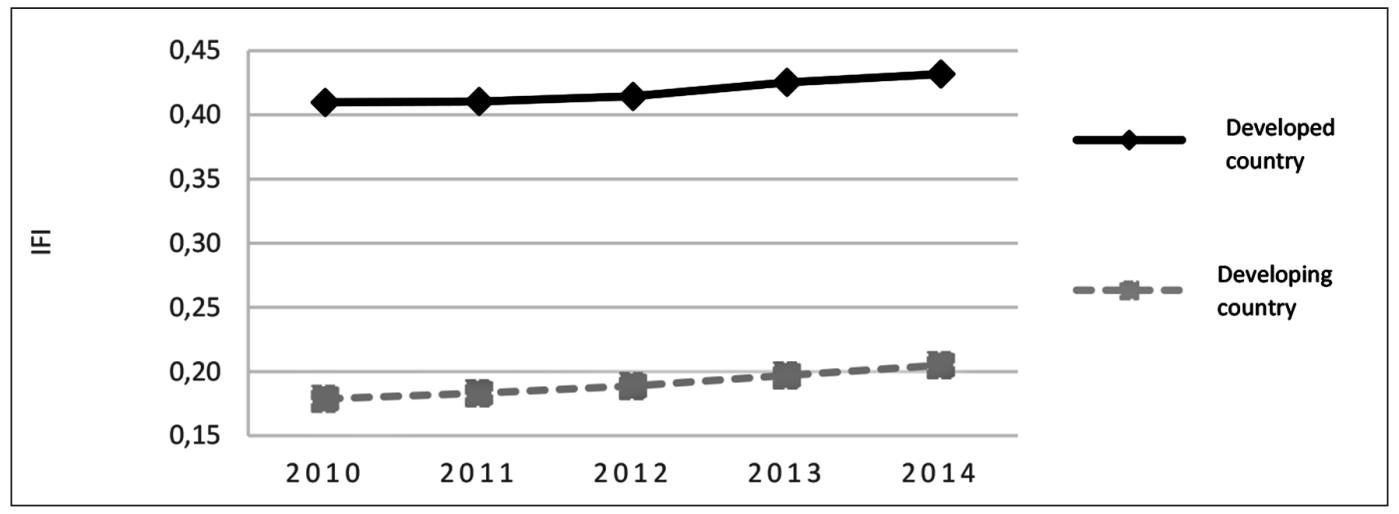

Source: Global Financial Inclusion Database, World Bank

A survey conducted by Demirgüc-Kunt dan Klapper (2012) showed that one of five adult populations in developed countries had no access to the formal financial institution. Almost $90 \%$ of societies in developing countries do not have access to the formal financial 
institution. It means the availability of formal financial services has not yet reached by the people in developing countries as a whole. Data published by the World Bank (2016) showed that 21.34 of the total number of commercial bank branches serve 100,000 adult populations in developed countries in 2014. It represents that a bank branch office serves approximately 4,762 adult populations. Meanwhile, a commercial bank branch in developing countries serves almost 33,333 adult populations in 2014. It implies that formal financial institutions in developing countries are unavailable for society as a whole.

Financial inclusion aims to increase a country's economic growth through decreasing income gap and poverty rate, and also to improve financial system stability. Research conducted by Jabir (2015) found that financial inclusion affected poverty reduction in Sub-Saharan Africa countries, so society gained increased welfare. Research conducted by Dienillah (2016) found financial inclusion had a positive and significant impact on financial system stability in high-income countries. But, there is no significant impact in low-income and middle-income countries.

Financial inclusion not only has an impact on economic growth, poverty levels, and financial system stability, it also has an impact on monetary policy effectiveness. Mehrotra and Yetman (2015) argued that financial inclusion has an indirect correlation with aggregate income. Therefore, the financial inclusion could help the monetary authority to control the inflation and monetary stability. Furthermore, Khan (2011) stated that interest rates could be as potential instruments to be used for monetary authorities if the country's IFI is high. Nevertheless, no particular literature has been used to analyze the impact of financial inclusion on demand for money.

Demand for money is one of the factors that affect the implementation of monetary policy. The variable of demand for money is an important thing to be studied intensively. This phenomenon is because a precise estimation of demand for money could be as relevant information for some economic and monetary policy decisions (Columba 2009). First, a accurate demand for money estimation is relevant for estimating the inflation rate (Attanasio et al., 2002; Lucas, 2000). Second, an accurate demand for money estimation could be used to understand the long-term correlation between money demand, inflation rate, and country's output (Friedmann 1969). Third, a precise demand for money estimation could be used to detect changes of public money demand schemes that caused by financial innovation.

This study attempts to analyze the impact of financial inclusion against the demand for reserve money (M0). Reserve money (M0) is one of the crucial components of monetary aggregates in the creation of money supply. Reserve money (M0) has a primary role in the money supply creation (currency in circulation, M1, and M2) either held by the public or saved in commercial banks. The literature about financial inclusion's impact on reserve money (M0) demand is still rare to study, so this topic could be interested in further analysis.

The research aims to compute and analyze index of financial inclusion (IFI). Moreover, this study also examines the impact of financial inclusion on demand for reserve money (M0) in 36 countries for the period 2004-2014. 


\section{Method}

This study observes some variables from 36 countries in the world (the list of countries presented in Appendix (Table A) from 2004 to 2014 that obtained from various sources. They are from the Global Financial Inclusion Database accessed through the World Bank, International Financial Statistics (IFS) and Financial Access Survey accessed through the International Monetary Fund (IMF) website. This study categorizes 36 countries into two groups of countries. First, a developed country is a country has an average GDP per capita more than US\$10,000 from 2004 to 2014 . Second, a developing country is a country has an average GDP per capita less than US\$10,000 from 2004 to 2014.

The first step conducted in this research is computing index of financial inclusion (IFI), as a proxy for the degree of financial inclusion. The measurement of the IFI is similar to research, which observed by Sarma (2008). The index consists of three basic dimensions: banking penetration ( $\mathrm{d} 1)$, availability of the banking services $(\mathrm{d} 2)$, and usage of the banking system (d3). The indicator of banking penetration (d1) is some deposit accounts in banks per 1,000 adult populations. The number of bank branches per 100,000 adult population as an indicator of banking services availability $(\mathrm{d} 2)$. Outstanding loans and deposits from commercial banks (\% of GDP) are indicators of the banking system usage ( $\mathrm{d} 3$ ). The dimension index for the ith dimension, di, is computed by the following equation (1):

Where:

$$
d_{i}=w_{i} \frac{A_{i}-m_{i}}{M_{i}-m_{i}}
$$

$d_{i}$ is dimension index for the $i_{t h} ; w_{i}$ is weight attached to the dimension $i, 0 \leq w_{i} \leq 1 ; A_{i}$ is actual value of dimension $i$; $M_{i}$ is the upper limit on the value of dimension $i$, fixed by some pre-specified rule; $m_{i}$ is the lower limit on the value of dimension $i$, fixed by some prespecified rule.

Equation (1) ensures that $0 \leq d_{i} \leq 1$. The higher the value of $d_{i}$, the higher the country's achievement in dimension $i$. Each dimension is assumed to have an equally important function, so the weight attached to each dimension is $w_{i}=1$.

The first step is computed $X_{1}$ and $X_{2} . X_{1}$ is the distance of normality $\mathrm{X}$ from the lowest point $\mathrm{O}$ (distance between $\mathrm{X}$ and $\mathrm{O}$ ). $X_{2}$ is the normality distance $\mathrm{X}$ with the ideal point $w$ (inverse distance between $\mathrm{X}$ and $\mathrm{w}$ ). The values of $X_{1}$ and $X_{2}$ are computed by the following equation (2) and (3):

$$
\begin{aligned}
& \mathrm{X}_{1}=\frac{\sqrt{d_{1}^{2}+d_{2}^{2}+\cdots+d_{n}^{2}}}{\sqrt{w_{1}^{2}+w_{2}^{2}+\cdots+w_{n}^{2}}} \\
& \mathrm{X}_{2}=1-\frac{\sqrt{\left(w_{1}-d_{1}\right)^{2}+\left(w_{2}-d_{2}\right)^{2}+\cdots+\left(w_{n}-d_{n}\right)^{2}}}{\sqrt{w_{1}^{2}+w_{2}^{2}+\cdots+w_{n}^{2}}}
\end{aligned}
$$

The distance $X_{1}$ and $X_{2}$ are normalized by the distance between $\mathrm{W}$ and $\mathrm{O}$ and this value is between 0 and 1 , thus the IFI value also will be between 0 and 1 . Then take a simple 
average of to compute index of financial inclusion (IFI). It is computed by the following equation (4):

$$
\mathrm{IFI}=\frac{1}{2}\left[\mathrm{X}_{1}+\mathrm{X}_{2}\right]
$$

Figure 2 illustrates a graphical explanation of a 3-dimensional IFI. A country that has an inclusive financial system should be closer to the ideal point W. Moreover, a country that has inclusive financial system should be farther away from the point $O$. In other words, the closer distance between the points $\mathrm{X}$ and $\mathrm{W}$ and more farther distance between $\mathrm{X}$ and $\mathrm{O}$ will indicate high financial inclusion simultaneously in country i. Sarma (2008) categorized the level of IFI into three groups: high financial inclusion $(0.5<\mathrm{IFI} \leq 1)$, medium financial inclusion $(0.3 \leq \mathrm{IFI}<0.5)$, and low financial inclusion $(0 \leq \mathrm{IFI}<0.3)$.

Figure 2. Graphical explanation of a 3-dimensional IFI

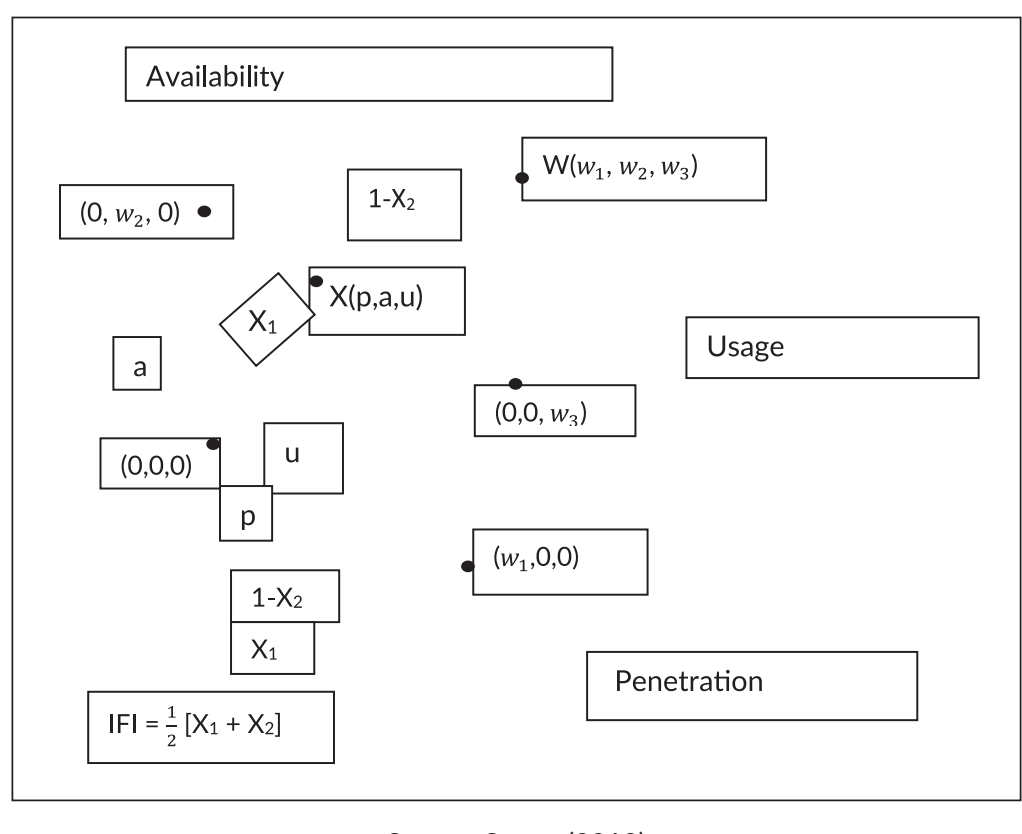

Source: Sarma (2012)

Also, this study also analyzed the impact of financial inclusion towards reserve money (M0) by using dynamic panel data analysis. Dynamic panel data characterized by the presence of a lagged dependent variable among the regression (Baltagi 2005), as follows:

$$
y_{i t}=\delta y_{i, t-1}+x^{\prime}{ }_{i t} \beta+u_{i t}
$$

where: $\delta$ is scalar, $\mathrm{x}_{\mathrm{it}}^{\prime}$ is $1 \times \mathrm{K}$, and $\beta \mathrm{Kx} 1$. Error $\mathrm{u}_{\mathrm{it}}$ assumed that it follows a model one-way component error model:

$$
u_{i t}=\mu_{i}+v_{i t}
$$

where: $\mu_{i} \sim I I D\left(0, \sigma_{\mu}^{2}\right)$ and $v_{i t} \sim I I D\left(0, \sigma_{v}^{2}\right)$ are independent of each other and among themselves (Baltagi 2005).

In determining the best model, dynamic panel or GMM model must comply three criteria (Firdaus 2011). First, the non-biased test compares the lagged coefficient of the dependent variable that is generated from the Arellano-Bond estimation, which is between 
dependent variable lagged coefficients, is between PLS and FEM. PLS estimator is biased upward and FEM estimator is biased downward. The estimator is not biased if the dependent variable lagged coefficient generated from Arellano-Bond, which is between of the coefficients of the dependent variable lag of PLS, and FEM.

Second, the consistency of dynamic panel approach is based on Arellano-Bond $A R\left({ }_{1}\right)$ and $A R(2)$ test results. The consistent condition happened when $A R(1)$ shows the rejected null hypothesis (significant) and $A R(2)$ shows the not rejected null hypothesis (not significant). Third, the validity of dynamic model resulted from Sargan test result. The estimator is valid when the Sargan test shows a level of significance more than $1 \%, 5 \%$, and $10 \%$ or the null hypothesis is not rejected.

Based on the standard model specification, money demand is a function of income and opportunity cost of holding money (Achsani 2010). The traditional money demand function is:

$$
M^{d}=f(y, i)
$$

where $M^{d}$ is riil demand for money, $y$ is real income, and $i$ is interest rate which is represent the opportunity cost of holding money. This study adopted the money demand equation from Dasril (2017), as follow

$$
\ln M 2_{i t}=\beta_{0 i t}+\beta_{1} \operatorname{lnGDPR} R_{i t}+\beta_{2} \text { Deposit }_{i t}+\beta_{3} I F I_{i t}+\varepsilon_{i t}
$$

M2 is real M2, GDPR real GDP, Deposit is deposit rate, IFI is index of financial inclusion, and $\varepsilon$ is error term.

Formulation of demand for reserve money function as follows:

$$
\ln M 0_{i t}=\alpha_{0 i t}+\alpha_{1} \ln M 0_{i, t-1}+\alpha_{2} \operatorname{lnGDPR_{it}}+\alpha_{3} D R_{i t}+\alpha_{4} I F I_{i t}+\varepsilon_{i t}(8)
$$

The dependent variable, $\ln M 0_{i t}$, is the $\log$ of real reserve money at time $\mathrm{t}$ and cross section i. $\ln G D P R$ is the $\log$ of real GDP, DR is the average deposit rate and represents own return of money, and IFI is index of financial inclusion. Theory predicts that $\alpha_{2}>0$ an increase in real GDP results in a higher demand for money, $\alpha_{3}>0$ an increase in interest rate results a lower demand for money. Whereas, the coefficient for index of financial inclusion (IFI), $\alpha_{4}$, can either be positive or negative.

\section{Result and Discussion}

Financial inclusion is necessary to implement because it could empower poor society to get better welfare. Also, financial inclusion could increase the poor society participation in the economic growth and encourage inclusive growth eventually (Sanjaya and Nursechafia 2016). Table 1 shows descriptive statistics about a Three-dimensional index of financial inclusion in 36 countries for the period 2004 until 2014. The indicators used in this analysis are Minimum (Min), Maximum (Max), Average (Avg), and Standard Deviation. On average, the financial inclusion index in 36 countries was 0.183 in 2004 and 0.243 in 2014. It implies that the financial inclusion index has a relatively little increase over the period. The usability dimension has the highest index on the IFI, followed by the availability and penetration dimensions. 
Zelin Nurfadia Sidik

Financial Inclusion and Demand for Money

Table 1. Three-Dimensional Index of Financial Inclusion

\begin{tabular}{|c|c|c|c|c|c|c|c|c|c|c|c|}
\hline \multirow{2}{*}{ Stat. } & \multicolumn{11}{|c|}{ Year } \\
\hline & 2004 & 2005 & 2006 & 2007 & 2008 & 2009 & 2010 & 2011 & 2012 & 2013 & 2014 \\
\hline \multicolumn{12}{|c|}{ Index of Financial Inclusion } \\
\hline Min & 0.031 & 0.034 & 0.034 & 0.036 & 0.040 & 0.042 & 0.046 & 0.049 & 0.047 & 0.049 & 0.050 \\
\hline Max & 0.667 & 0.661 & 0.654 & 0.645 & 0.649 & 0.667 & 0.660 & 0.671 & 0.677 & 0.685 & 0.688 \\
\hline Avg & 0.183 & 0.189 & 0.194 & 0.204 & 0.210 & 0.217 & 0.217 & 0.221 & 0.226 & 0.235 & 0.243 \\
\hline St. Dev & 0.149 & 0.148 & 0.146 & 0.144 & 0.142 & 0.144 & 0.142 & 0.146 & 0.147 & 0.151 & 0.151 \\
\hline \multicolumn{12}{|c|}{ Penetration Index } \\
\hline Min & 0.000 & 0.000 & 0.002 & 0.005 & 0.007 & 0.008 & 0.009 & 0.009 & 0.010 & 0.010 & 0.009 \\
\hline Max & 1.000 & 0.980 & 0.949 & 0.911 & 0.898 & 0.892 & 0.890 & 0.894 & 0.906 & 0.910 & 0.908 \\
\hline Avg & 0.120 & 0.126 & 0.130 & 0.133 & 0.139 & 0.143 & 0.147 & 0.154 & 0.163 & 0.173 & 0.180 \\
\hline St. Dev & 0.185 & 0.179 & 0.175 & 0.169 & 0.166 & 0.166 & 0.165 & 0.167 & 0.170 & 0.174 & 0.175 \\
\hline \multicolumn{12}{|c|}{ Availability Index } \\
\hline Min & 0.007 & 0.014 & 0.015 & 0.015 & 0.017 & 0.018 & 0.023 & 0.024 & 0.025 & 0.027 & 0.027 \\
\hline Max & 0.802 & 0.794 & 0.778 & 0.773 & 0.801 & 0.761 & 0.765 & 0.921 & 0.957 & 0.992 & 1.000 \\
\hline Avg & 0.186 & 0.191 & 0.199 & 0.213 & 0.225 & 0.225 & 0.225 & 0.231 & 0.237 & 0.243 & 0.251 \\
\hline St. Dev & 0.175 & 0.172 & 0.174 & 0.184 & 0.192 & 0.187 & 0.186 & 0.199 & 0.203 & 0.207 & 0.210 \\
\hline \multicolumn{12}{|c|}{ Usability Index } \\
\hline Min & 0.049 & 0.053 & 0.056 & 0.071 & 0.079 & 0.080 & 0.087 & 0.089 & 0.082 & 0.083 & 0.088 \\
\hline Max & 0.806 & 0.839 & 0.829 & 0.838 & 0.808 & 0.852 & 0.848 & 0.859 & 0.905 & 0.979 & 1.000 \\
\hline Avg & 0.227 & 0.235 & 0.239 & 0.249 & 0.250 & 0.267 & 0.264 & 0.264 & 0.267 & 0.278 & 0.287 \\
\hline St. Dev & 0.172 & 0.176 & 0.174 & 0.170 & 0.163 & 0.175 & 0.169 & 0.173 & 0.178 & 0.186 & 0.187 \\
\hline
\end{tabular}

The result indicates that the usability of the banking system primarily determines financial inclusion in 36 countries. This result is illustrated by the high normalization value of outstanding loans and deposits from a commercial bank (\% of GDP) than other dimensions. The lack accessibility of formal financial institutions illustrated by low penetration of formal financial institutions and proportion of adults who have an account in formal financial institutions. They could be an obstacle for implementing program of financial inclusion.

The estimation of dynamic panel model of demand for reserve money shown in The Appendix (Table B). First, the non-biased test shows the Arellano-Bond lagged dependent variable coefficient $(\operatorname{lnM} 0 \mathrm{t}-1)$ is between PLS and FEM estimator. It implies that non-biased requirement has complied. Second, the estimation of reserve money (M0) demand model is already consistent, where the null hypothesis statistical value of $\mathrm{AR}(1)$ rejected, and $\mathrm{AR}(2)$ not rejected. Third, demand for reserve money (M0) model is already valid. It because the Sargan test shows the null hypothesis is not rejected (H0: valid instrument). 
Real gross domestic product ( $\operatorname{lnGDPr}$ ) represents income that used to measures the money as a medium of exchange. Real GDP has a positive impact towards demand for reserve money (M0) in developed countries, developing countries, and full samples. But that effect is only significant in the developing country with a significance level of five percent. The positive correlation between these two variables implies that the increase of income is in line with increasing welfare, people will spend and need more money, so the demand for money would be an increase. This result is appropriate with the Keynesian's theory of liquidity preferences that states that the transactions and precautionary motives reflect money as a medium of exchange. So, income variable has a major role in determining the demand for money (Dunne and Kasakende 2016).

Research conducted by Hafer and Kutan (2003) found real income had a positive and significant impact on demand for reserve money (M0) in the Philippines. Sichei and Kamau (2012) also found that the increase of real income may stimulate the rise of demand for reserve money (M0). This fact is because the rise of real output would lead the increasing expenditure as well, so it will increase demand for money.

The coefficient of deposit rate (Deposit) has a positive and significant impact on reserve money (M0) in developed and developing countries that have the significance level of ten percent and one percent respectively. In the other hand, the positive effect of interest rate for reserve money (M0) is not significant in full samples.

Reserve money (M0) is one of the monetary instruments that consist of currency in circulation and demand deposits owned by society and commercial banks that saved in the central bank. Demand deposits give a return for customers, such as interest rate. The interest rate on demand deposits follows the deposit interest rate changing which is announced by the central bank. It means if the central bank announces that the increasing deposit interest rate would be the increase the interest rate on demand deposits. The private sector and banks are encouraged to save their money on demand deposits. This condition would cause the rise in demand for reserve money (M0). The positive correlation between deposit rates and demand for reserve money (M0) is in line with research conducted by Sichei and Kamau (2012).

The interaction among index of financial inclusion (IFI) and demand for reserve money (M0) has a different effect in developed and developing countries. Financial inclusion has a positive and significant impact on reserve money (M0) demand in developed countries and full samples, with significance level at one percent and five percent, respectively. It implies that the increasing of IFI lead to the increase in demand for reserve money (M0).

Index of financial inclusion (IFI) has a negative impact for reserve money (M0) but insignificant in developing countries. This result implies that improvement of banking penetration, availability of banking services, and usability of the banking system could reduce the demand for reserve money (M0). This result is in line with research conducted by Hafer and Kutan (2003), they found that financial innovation, it related positively with financial inclusion, is associated with the decreasing of reserve money (M0) growth in the Philippines. 


\section{Conclusion}

Financial inclusion is implemented to facilitate unbanked people in utilizing formal financial institutions services with affordable cost and low barriers to access. By using a 3-dimensional index of financial inclusion, it concluded that the level of financial inclusion had increased continuously. The convenience of accessing formal financial services and also the reduction of a barrier to access it are still needed to reach more comprehensive financial system for the society.

Financial inclusion has different impacts on demand for reserve money (M0) among the group of countries. In developed countries, financial inclusion affects reserve money (M0) positively and significantly. Otherwise, the increase in the accessibility, availability, and usability of formal financial services cause the decreasing of demand for reserve money (M0). The increasing of IFI shows that the financial system would develop massively. It would affect the velocity of money. Therefore, the monetary authority should control and regulate the demand for reserve money (M0). Considering the demand for reserve money is an essential component in the money supply creation process.

\section{References}

Achsani, N. A. (2010). Stability of Money Demand in an Emerging Market Economy: an Error Correction and ARDL model for Indonesia. Research Journal of International Studies. Vol. 13: 54-62.

Attanasio, O. P., Guiso, L., \& Jappelli, T. (2002). The Demand for Money, Financial Innovation, and The Welfare Cost of Inflation: An Analysis With Household Data. Journal of Political Economy. Vol. 110(2): 317-351. doi: https://doi.org/10.1086/338743.

Baltagi, B. H. (2005). Econometric Analysis of Panel Data (3'd Ed). Chichester UK: John Wiley \& Sons, Ltd.

Columba, F. (2009). Narrow Money and Transaction Technology: New Disaggregated Evidence. Munich Personal RePec Archive (MPRA) Paper. 12689.

Dasril, R. O. (2017). Dampak Inklusi Keuangan Terhadap Permintaan Uang (The Impact of Financial Inclusion to Demand of Money). (Unpublished Thesis). Bogor: Bogor Agricultural University.

Demirgüc-Kunt, A., \& Klapper, L. F. (2012). Measuring Financial Inclusion: The Global findex database. Policy Research Working Paper. World Bank. 6025:1-58.

Dienillah, A. A., \& Anggraeni, L. (2016). Dampak Inklusi Keuangan Terhadap Stabilitas Sistem Keuangan di Asia (The Impact of Financial Inclusion on Financial System Stability in Asia). Buletin Ekonomi Moneter dan Perbankan. Vol. 18(4): 409-430.

Dunne, J. P., \& Kasekende, E. (2016). Financial Innovation and Money Demand: Evidence From Sub-Saharan Africa. Economic Research Southern Africa (ERSA) Working Paper. 583.

Firdaus, M. (2011). Aplikasi Ekonometrika untuk Data Panel dan Time Series (Econometric Application for Panel Data and Time Series). Bogor: IPB Press. 
Hafer, R. W., \& Kutan, A. M. (2010). Financial Innovation and The Demand for Money: Evidence From The Philippines. International Economic Journal. Vol. 17(1): 17-27. doi: https://doi.org/10.1080/10168730300080002.

Khan, H. R. (2011). Financial Inclusion and Financial Stability: Are They Two Sides of The Same Coin? Retrieved from: https://www.bis.org/review/r111229f.pdf.

Lucas, R. E. (2000). Inflation and Welfare. Econometrica. Vol. 68(2): 247-274. doi: https:// doi.org/10.1111/1468-0262.00109.

Mehrotra, A., \& Yetman, J. (2015). Financial Inclusion-Issue for Cental Banks. BIS Quartely review, Bank for International Settlements. 83-96.

Sanjaya, I. M., \& Nursechafia. (2016). Inklusi Keuangan dan Pertumbuhan Inklusif: Analisis Antar provinsi di Indonesia (Financial Inclusion and Inclusive Growth: Cross-Province Analysis in Indonesia). Buletin Ekonomi Moneter dan Perbankan. Vol. 18(3): 281-306.

Sarma, M. (2008). Index of Financial Inclusion. Indian Council for Research on International Economic Relations Working Paper. 215:1-20.

Sarma, M. (2012). Index of Financial Inclusion-A Measure of Financial Sector Inclusiveness. Berlin Working Papers on Money, Finance, Trade, and Development. 07:1-37.

Sichei, M. M., \& Kamau, A. W. (2012). Demand for Money: Implications For The Conduct of Monetary Policy in Kenya. International Journal of Economics and Finance. Vol. 4(8): 72-82. doi: https://doi.org/10.5539/ijef.v4n8p72. 
Zelin Nurfadia Sidik

Financial Inclusion and Demand for Money

\section{Appendix}

Table A. List of Countries

\begin{tabular}{|c|c|c|c|c|c|c|}
\hline \multicolumn{3}{|c|}{ Developed Countries } & \multicolumn{4}{|c|}{ Developing Countries } \\
\hline $\begin{array}{c}\text { Czech } \\
\text { Republic }\end{array}$ & South Korea & Switzerland & South Africa & Guatemala & Kenya & Pakistan \\
\hline \multirow[t]{7}{*}{ Japan } & Kuwait & $\begin{array}{c}\text { Trinidad and } \\
\text { Tobago }\end{array}$ & Algeria & Guyana & Costa Rica & Samoa \\
\hline & & & Angola & Honduras & Malaysia & Seychelles \\
\hline & & & Armenia & Hungary & Mexico & Solomon \\
\hline & & & Bangladesh & Indonesia & Moldova & Tanzania \\
\hline & & & Bolivia & Jamaica & Mongolia & Uganda \\
\hline & & & Fiji & Jordan & Namibia & \\
\hline & & & Georgia & Cameroon & Nicaragua & \\
\hline
\end{tabular}




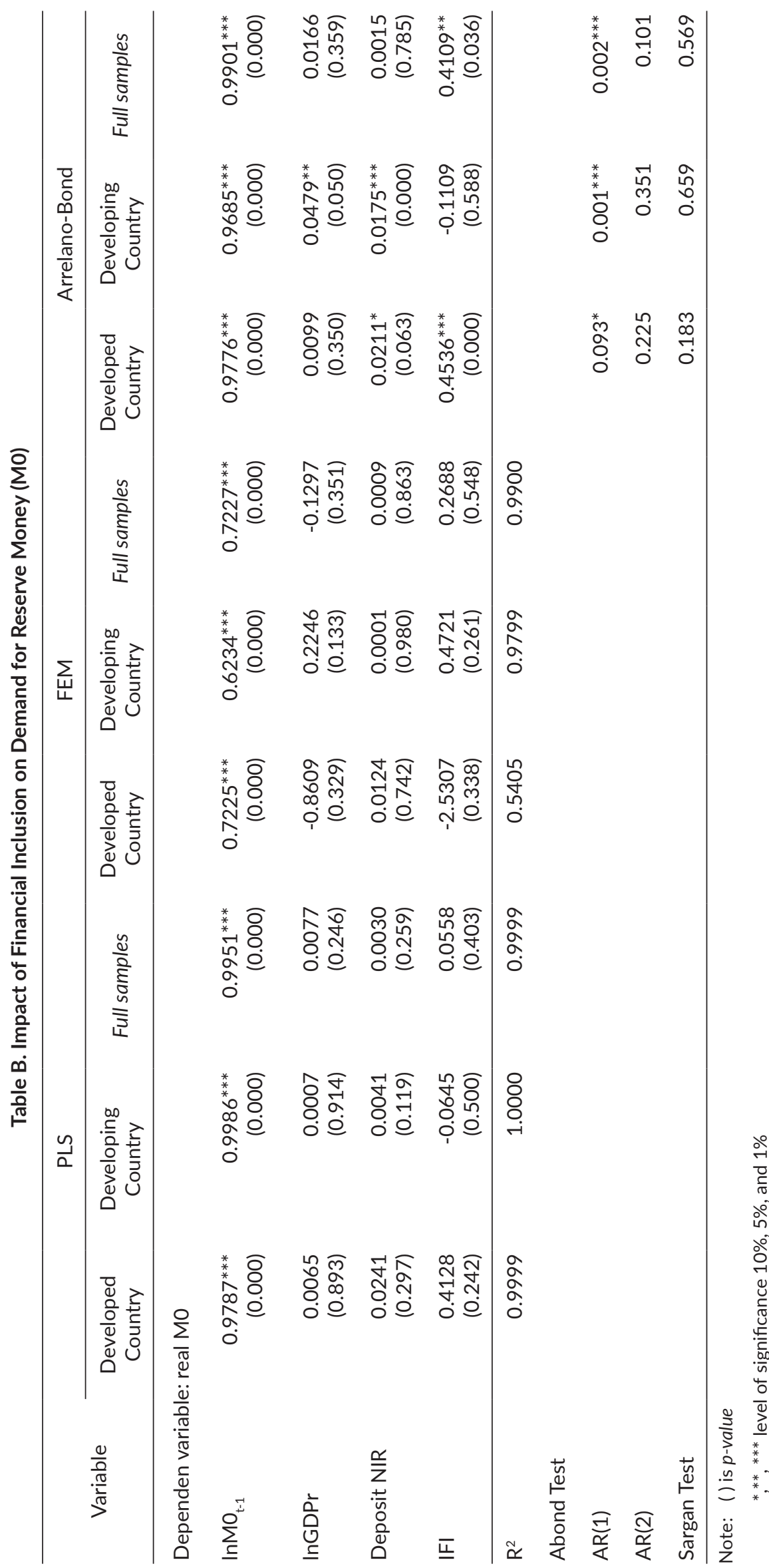

